\begin{tabular}{r|l|l|l}
$\begin{array}{r}\text { Case Reports in } \\
\text { Gastruenterology }\end{array}$ & $\begin{array}{l}\text { Case Rep Gastroenterol 2010;4:492-497 } \\
\text { DOI: 10.1159/000321091 }\end{array}$ & $\begin{array}{l}\text { Published online: } \\
\text { November 3, 2010 }\end{array}$ & $\begin{array}{l}\text { O 2010 S. Karger AG, Basel } \\
\text { ISSN 1662-0631 } \\
\text { www.karger.com/crg }\end{array}$ \\
\hline
\end{tabular}

This is an Open Access article licensed under the terms of the Creative Commons AttributionNonCommercial-NoDerivs 3.0 License (www.karger.com/OA-license), applicable to the online version of the article only. Distribution for non-commercial purposes only.

\title{
Jejunal Diverticulitis: A Rare Case of Severe Peritonitis
}

\author{
Sujit Vijay Sakpal ${ }^{\mathrm{a}}$ Kenneth Fried ${ }^{\mathrm{b}}$ \\ Ronald Scott Chamberlainc \\ aSurgery, Saint Barnabas Medical Center, Livingston, N.J.; ${ }^{\text {bEnglewood Hospital }}$ \\ and Medical Center, Englewood, N.J., and 'Saint Barnabas Medical Center, \\ Livingston, N.J., and University of Medicine and Dentistry of New Jersey, \\ Newark, N.J., USA
}

\section{Key Words}

Computed tomography · Diverticulitis · Jejunum - Laparoscopy · Small bowel

\begin{abstract}
A 25-year-old African American female with no prior medical/surgical history presented with abdominal pain and fever. A computed tomography scan of the abdomen and pelvis showed jejunal wall thickening with an air-fluid-filled mass in the adjacent mesentery. At laparotomy, a segmental jejunal resection with the abscess cavity followed by primary anastomosis was performed. Pathological evaluation of the specimen revealed a large mesenteric abscess contiguous with a perforated solitary jejunal diverticulum. We provide a discussion of jejunal diverticulitis as an unusual cause of peritonitis.
\end{abstract}

\section{Introduction}

Large bowel diverticuli are more frequent than small bowel diverticuli. Small bowel diverticuli are encountered most frequently in the duodenum [1], however complicated and symptomatic diverticuli occur most commonly in the jejunoileal region [2]. Small bowel diverticuli are pulsion lesions acquired by herniation of mucosa and submucosa through a weak muscularis layer, hence forming a false diverticulum. Complications of these diverticuli may have a varied symptomatology. Diagnosis of small bowel diverticuli is often made during diagnostic or therapeutic interventions for unrelated issues. While a small bowel barium study and enteroclysis are optimal diagnostic modalities for this disease, a computed tomography (CT) scan of the abdomen and pelvis is most ideal to identify the complications of small bowel diverticuli, such as formation of an abscess as was seen in our patient. If suspected, jejunal diverticulitis is best treated by either laparoscopic or open surgery. 


\begin{tabular}{r|l|l|l} 
Case Reports in & $\begin{array}{l}\text { Case Rep Gastroenterol 2010;4:492-497 } \\
\text { DOI: 10.1159/000321091 }\end{array}$ & $\begin{array}{l}\text { Published online: } \\
\text { November 3, 2010 }\end{array}$ & $\begin{array}{l}\text { ISSN 1662-0631 } \\
\text { www.karger.com/crg }\end{array}$ \\
\hline
\end{tabular}

\section{Case Report}

A 25-year-old African American female with no significant past medical or surgical history presented with moderate to severe abdominal pain and fever $\left(\mathrm{T}_{\max } 39.1^{\circ} \mathrm{C}\right)$ of three days duration. Pain was localized to the left lower quadrant and the periumbilical area. She experienced a single episode of bilious vomiting, but denied any other obstructive symptoms. She denied any similar episodes in the past. Her obstetric and gynecologic history was non-contributory. She denied any history of sexually transmitted diseases. Vital signs were normal. On physical exam, her abdomen was soft but diffusely tender with rebound and guarding. Laboratory findings revealed leukocytosis (WBC $13,600 / \mathrm{mm}^{3}$ ) and an elevated partial thromboplastin time (PTT 46). A pelvic ultrasound showed a small amount of free fluid in cul-de-sac, but no ovarian mass or uterine fibroids. A CT scan of the abdomen and pelvis (fig. 1) revealed a thickened jejunal wall with mild dilatation, several small adjacent enlarged mesenteric lymph nodes, and an air-fluid-containing structure measuring $1.9 \times 2.9 \mathrm{~cm}$ in the left abdomen. These findings suggested inflammatory or infectious enteritis with abscess formation.

The patient was taken to the operating room for an exploratory laparotomy. At exploration, diffuse serous fluid was encountered, and a segment of the proximal jejunum appeared erythematous and edematous. A large abscess cavity in the adjacent jejunal mesentery was also identified. Segmental resection of the involved jejunum and mesentery including the abscess cavity was performed followed by a side-to-side anastomosis. Pathological analysis of the resected specimen revealed a mesenteric abscess (fig. 2) in connection with a single diverticulum (fig. 2, fig. 3 ) of the jejunal wall.

Post-operatively, the patient had an uneventful recovery and was discharged home on hospital day 7.

\section{Discussion}

In a young female as the one described above, severe abdominal pain and tenderness with fever and leukocytosis, all of which suggest an acute abdomen, would draw a long list of differential diagnoses. The most common things would involve perforated appendicitis, ectopic pregnancy, pelvic inflammatory disease, tubo-ovarian abscess, or hemorrhagic or ruptured ovarian cysts. However, the CT scan image revealing an inflamed small bowel wall with an adjacent abscess was vital in determining the need for surgery. In retrospect, laparoscopy followed by segmental resection of the involved bowel and the abscess would have been preferable over open surgery.

Diverticuli occur throughout the small and large bowel. Large bowel diverticuli are more frequent and often present with complications. Small bowel diverticuli are encountered most frequently in the duodenum [1], but complications arise most often when they occur in the jejunoileal region [2]. Small bowel diverticuli are false diverticuli, which means they involve only the mucosa, submucosa and serosa, excluding the muscularis layer. Both duodenal and jejunoileal diverticuli are acquired pulsion lesions that may clinically present in a vague and diverse manner, such as epigastric or periumbilical abdominal pain, satiety, bloating, constipation and diarrhea. Although colonic diverticular disease may be one of the extrarenal manifestations of autosomal dominant polycystic kidney disease (ADPKD) [3], only a single case of small bowel diverticuli in a chronically hemodialysed ADPKD patient has been reported [4], and there is insufficient evidence to suggest an association between these two entities.

Duodenal diverticuli are common and found in $2-5 \%$ of patients undergoing upper gastrointestinal series [5]. The majority of these diverticuli are extraluminal and occur near the ampulla of Vater [6]. Etiologically most duodenal diverticuli are thought to be acquired by herniation of the mucosa and submucosa through a wall defect caused by entrance of large vessels. Rarely duodenal diverticuli are intraluminal, which may be congenital resulting from incomplete intestinal lumen canalization [7]. Clinically less 


\begin{tabular}{r|l|l|l}
$\begin{array}{r}\text { Case Reports in } \\
\text { Gastruenterology }\end{array}$ & $\begin{array}{l}\text { Case Rep Gastroenterol 2010;4:492-497 } \\
\text { DOI: 10.1159/000321091 }\end{array}$ & $\begin{array}{l}\text { Published online: } \\
\text { November 3, 2010 }\end{array}$ & $\begin{array}{l}\text { O 2010 S. Karger AG, Basel } \\
\text { ISSN 1662-0631 } \\
\text { www.karger.com/crg }\end{array}$ \\
\hline
\end{tabular}

than $10 \%$ of duodenal diverticuli are symptomatic with approximately $1 \%$ requiring definitive treatment [8]. Rare complications of duodenal diverticuli include obstruction, perforation, bleeding and diverticulitis, and interestingly they are strongly associated with a high frequency of common bile duct stones [6].

Jejunoileal diverticuli are found in 1-2\% of the general population [9] with most presenting during the sixth or seventh decade of life [10]. They usually occur in multiples and mostly in the proximal jejunum [5]. Jejunoileal diverticuli are frequently associated with intestinal motility disorders such as progressive systemic sclerosis, visceral neuropathies or myopathies [11]. Atrophy of the myopathic jejunal wall on one side and increased luminal pressure from the opposite leads to protrusion of small intestinal mucosa through defects in the lamina muscularis mucosae [12]. Jejunoileal diverticuli are mostly asymptomatic, but malabsorption due to bacterial overgrowth within them may be a major clinical feature. They may also present in unusual ways, such as with a gastrointestinal hemorrhage due to a ruptured congenital arteriovenous malformation in the diverticular submucosal [13], perforation with abscess progressing into a jejuno- [14] ileo- [15] abdominal wall fistula formation, or episodes of bowel obstruction secondary to volvulus [16], stricture formation [17] or an enterolith impaction [18-20]. Jejunal diverticulitis occurs in about $2-6 \%$ of cases and has a mortality rate as high as $24 \%$ [11].

Diagnosis of small bowel diverticuli is often incidental at endoscopic retrograde cholangiopancreatography [6], laparotomy, or double-balloon enteroscopy [21]. Although endoscopy (capsule and double-balloon) may diagnose intraluminal abnormalities of the small bowel, its utility in emergency is limited [11]. Barium follow-through and enteroclysis are the diagnostic modalities of choice for small bowel diverticuli. A CT scan of the abdomen and pelvis is most useful to identify abscess formation following diverticular perforation [22]. Although non-specific, this finding may suggest jejunoileal diverticulitis amongst other differential diagnoses, namely neoplasms, focal Crohn's disease, foreign body perforations, medication-induced ulcers and traumatic hematomas.

In the absence of contraindications, diagnostic laparoscopy is a useful tool that may allow a thorough intra-abdominal surveillance to reach a precise diagnosis [11]. Open or laparoscopic resection of the involved small bowel segment and primary anastomosis is indicated for jejunoileal diverticulitis, bowel perforation or bleeding [23, 24]. Approximately $15 \%$ of patients with jejunal diverticulosis may require small bowel resection for treatment of such complications [2]. Unlike colonic diverticulitis, conservative management involving bowel rest and antibiotic administration is rarely successful. Macari et al. have reported success in only one out of three patients with jejunal diverticulitis treated conservatively [25].

\section{Conclusions}

Jejunoileal diverticulosis and its associated complications are rare. Its preoperative diagnosis is difficult, but should be considered in cases of unexplained abdominal symptoms and peritonitis. Given the high mortality rate of jejunal diverticulitis, a precise diagnosis followed by appropriate therapeutic intervention is essential. If suspected, diagnostic laparoscopy unless contraindicated seems to be an apt approach to confirm the 


\begin{tabular}{r|l|l|l}
$\begin{aligned} & \text { Case Reports in } \text { Case Rep Gastroenterol 2010;4:492-497 } \\
& \text { DOl: 10.1159/000321091 }\end{aligned}$ & $\begin{array}{l}\text { Published online: } \\
\text { November 3, 2010 }\end{array}$ & $\begin{array}{l}\text { O 2010 S. Karger AG, Basel } \\
\text { ISSN 1662-0631 } \\
\text { www.karger.com/crg }\end{array}$ \\
\hline
\end{tabular}

diagnosis. Despite the successful outcome and uneventful recovery in our patient, we believe laparoscopic bowel resection may have been similarly beneficial in limiting the morbidity and recovery time associated with an open procedure.

\section{Disclosure Statement}

All the authors listed declare that there are no conflicts of interest and that they accepted no financial sponsorship in producing and presenting this article.

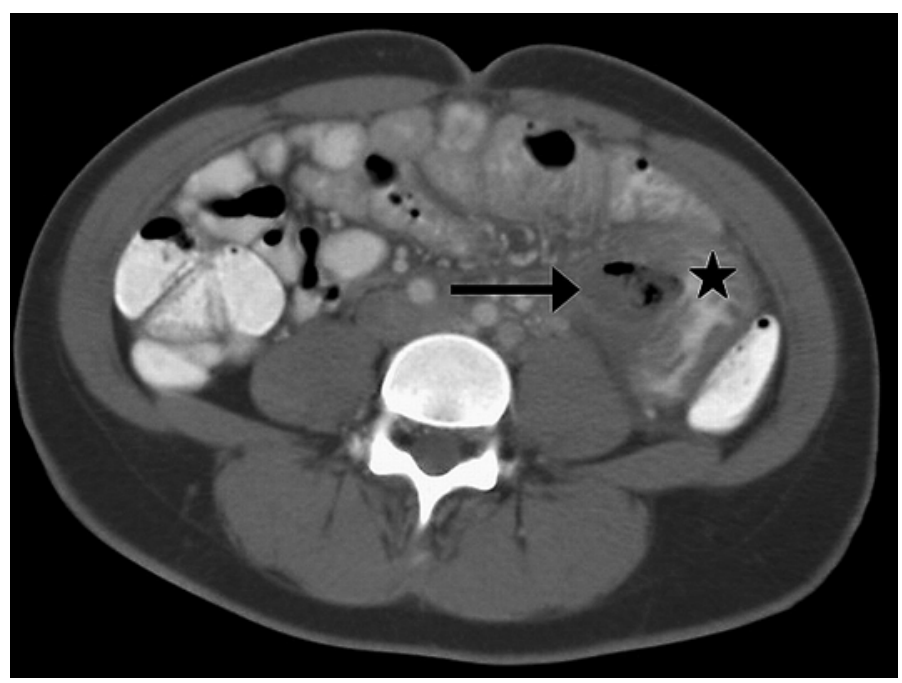

Fig. 1. A CT scan of the abdomen and pelvis demonstrated a thickened loop of jejunum (star) in the left abdomen with an adjacent air-fluid-filled mass (arrow) measuring $2.9 \mathrm{~cm}$ in the largest diameter. 


\begin{tabular}{l|l|l|l}
$\begin{array}{r}\text { Case Reports in } \\
\text { Gastruenterology }\end{array}$ & $\begin{array}{l}\text { Case Rep Gastroenterol 2010;4:492-497 } \\
\text { DOI: 10.1159/000321091 }\end{array}$ & $\begin{array}{l}\text { Published online: } \\
\text { November 3, 2010 }\end{array}$ & $\begin{array}{l}\text { O 2010 S. Karger AG, Basel } \\
\text { ISSN 1662-0631 } \\
\text { www.karger.com/crg }\end{array}$ \\
\hline
\end{tabular}

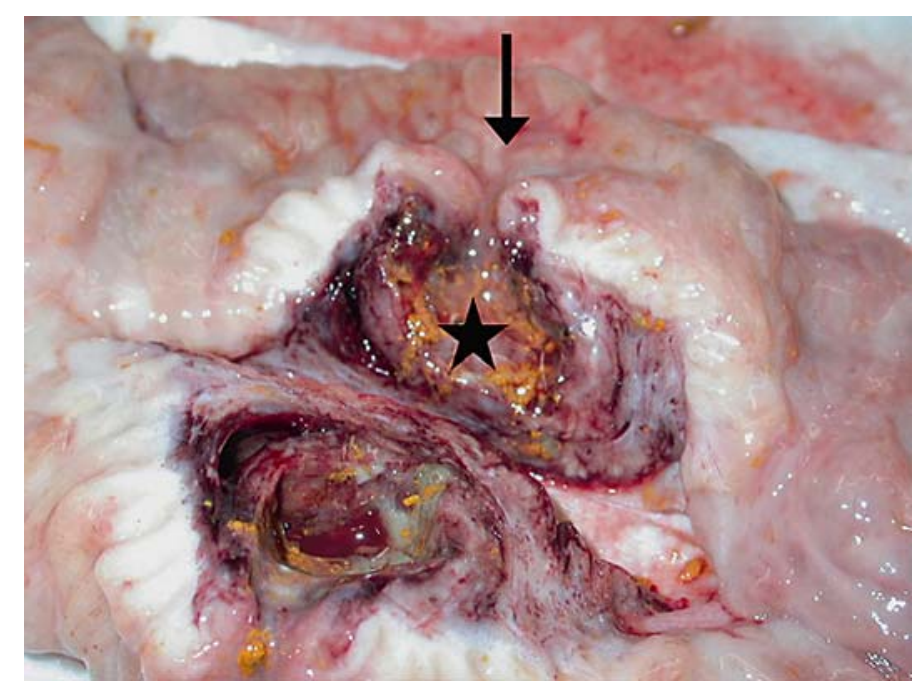

Fig. 2. Photo exhibits a dissected view of the mesenteric abscess. Clearly evident is the jejunal diverticulum (arrow) opening into the abscess cavity (star).

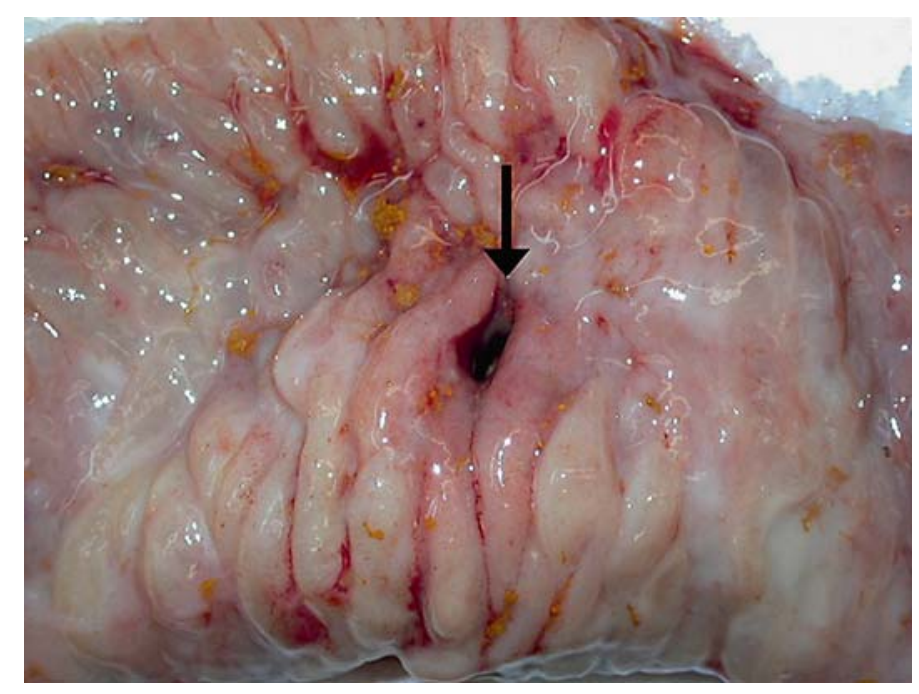

Fig. 3. Gross specimen of the resected proximal segment of the jejunum. Shown in the photo is the opening (arrow) of a solitary diverticulum on the intra-luminal surface of the jejunal wall.

\section{References}

1 Akhrass R, Yaffe MB, Fischer C, Ponsky J, Shuck JM: Small-bowel diverticulosis: perceptions and reality. J Am Coll Surg 1997;184:383-388.

2 Cunningham SC, Gannon CJ, Napolitano LM: Small-bowel diverticulosis. Am J Surg 2005;190:37-38.

3 Perrone RD: Extrarenal manifestations of ADPKD. Kidney Int 1997;51:2022-2036.

4 Peña JM, Pernaute R, Vicente de Vera C: Is ADPKD associated with small-bowel diverticular disease? Nephrol Dial Transplant 2000;15:1890-1891.

5 Afridi SA, Fichtenbaum CJ, Taubin H: Review of duodenal diverticula. Am J Gastroenterol 1991;86:935-938. 
6 Leivonen MK, Halttunen JA, Kivilaakso EO: Duodenal diverticulum at endoscopic retrograde cholangiopancreatography, analysis of 123 patients. Hepatogastroenterology 1996;43:961-966.

7 Fleming CR, Newcomer AD, Stephens DH, Carlson HC: Intraluminal duodenal diverticulum. Report of two cases and review of the literature. Mayo Clin Proc 1975;50:244-248.

-8 Psathakis D, Utschakowski A, Müller G, Broll R, Bruch HP: Clinical significance of duodenal diverticula. J Am Coll Surg 1994;178:257-260.

9 Maglinte DD, Chernish SM, DeWeese R, Kelvin FM, Brunelle RL: Acquired jejunoileal diverticular disease: subject review. Radiology 1986;158:577-580.

-10 Yağmur Y, Aldemir M, Büyükbayram H, Taçyildiz I: Multiple jejunal diverticulitis with perforation in a patient with systemic lupus erythematosus: report of a case. Surg Today 2004;34:163-166.

-11 Kassahun WT, Fangmann J, Harms J, Bartels M, Hauss J: Complicated small-bowel diverticulosis: a case report and review of the literature. World J Gastroenterol 2007;13:2240-2242.

-12 Krishnamurthy S, Kelly MM, Rohrmann CA, Schuffler MD: Jejunal diverticulosis: a heterogenous disorder caused by a variety of abnormalities of smooth muscle or myenteric plexus. Gastroenterology 1983;85:538-547.

13 Chin NW, Lai CH, Harisiadis SA, Chapman I: Congenital arteriovenous malformation rupturing into a true jejunal diverticulum. Am J Gastroenterol 1989;84:972-974.

-14 Sakurai Y, Tonomura S, Yoshida I, Masui T, Shoji M, Nakamura Y, Matsubara T, Uyama I, Komori Y, Ochiai M: Abdominal wall abscess associated with perforated jejunal diverticulitis: report of a case. Surg Today 2005;35:682-686.

15 Eriguchi N, Aoyagi S, Nakayama T, Emi Y, Saku M, Yoshida K: Ileo-abdominal wall fistula caused by diverticulum of the ileum. J Gastroenterol 1998;33:272-275.

16 Chiu KW, Changchien CS, Chuah SK: Small-bowel diverticulum: is it a risk for small-bowel volvulus? J Clin Gastroenterol 1994;19:176-177.

-17 Shanmugam RP, Shivakumar P: A rare complication of jejunal diverticulosis. Trop Gastroenterol 2006;27: 134-135.

18 Harris LM, Volpe CM, Doerr RJ: Small bowel obstruction secondary to enterolith impaction complicating jejunal diverticulitis. Am J Gastroenterol 1997;92:1538-1540.

-19 Klingler PJ, Seelig MH, Floch NR, Branton SA, Metzger PP: Small-intestinal enteroliths - unusual cause of small-intestinal obstruction: report of three cases. Dis Colon Rectum 1999;42:676-679.

20 Lobo DN, Braithwaite BD, Fairbrother BJ: Enterolith ileus complicating jejunal diverticulosis. J Clin Gastroenterol 1999;29:192-193.

-21 Kamal A, Gerson LB: Jejunal diverticulosis diagnosed by double-balloon enteroscopy. Gastrointest Endosc 2006;63:864.

-22 Gayer G, Zissin R, Apter S, Shemesh E, Heldenberg E: Acute diverticulitis of the small bowel: CT findings. Abdom Imaging 1999;24:452-455.

-23 Tsiotos GG, Farnell MB, Ilstrup DM: Nonmeckelian jejunal or ileal diverticulosis: an analysis of 112 cases. Surgery 1994;116:726-731.

24 Palder SB, Frey CB: Jejunal diverticulosis. Arch Surg 1988;123:889-894.

25 Macari M, Faust M, Liang H, Pachter HL: CT of jejunal diverticulitis: imaging findings, differential diagnosis, and clinical management. Clin Radiol 2007;62:73-77.

Each of the authors listed is in agreement with the content of this paper. 